OPEN ACCESS

Edited by:

Ren-Shan Ge,

Wenzhou Medical University, China

Reviewed by:

T. Rajendra Kumar,

University of Colorado Anschutz Medical Campus, United States

Thomas A. Masterson, University of Miami Health System,

United States

*Correspondence:

Livio Casarin

livio.casarini@unimore.it

Specialty section

This article was submitted to Reproduction, a section of the journal

Frontiers in Endocrinology

Received: 19 September 2018 Accepted: 29 April 2019 Published: 14 May 2019

Citation: Casarini L and Crépieux P (2019) Molecular Mechanisms of Action of FSH. Front. Endocrinol. 10:305 doi: 10.3389/fendo.2019.00305

\section{Molecular Mechanisms of Action of FSH}

\author{
Livio Casarini $^{1,2 *}$ and Pascale Crépieux ${ }^{3}$ \\ ${ }^{1}$ Unit of Endocrinology, Department Biomedical, Metabolic and Neural Sciences, University of Modena and Reggio Emilia, \\ Modena, Italy, ${ }^{2}$ Center for Genomic Research, University of Modena and Reggio Emilia, Modena, Italy, ${ }^{3}$ PRC, UMR \\ INRA0085, CNRS 7247, Centre INRA Val de Loire, Nouzilly, France
}

The glycoprotein follicle-stimulating hormone (FSH) acts on gonadal target cells, hence regulating gametogenesis. The transduction of the hormone-induced signal is mediated by the $\mathrm{FSH}$-specific G protein-coupled receptor (FSHR), of which the action relies on the interaction with a number of intracellular effectors. The stimulatory Gas protein is a long-time known transducer of FSH signaling, mainly leading to intracellular CAMP increase and protein kinase $A(P K A)$ activation, the latter acting as a master regulator of cell metabolism and sex steroid production. While in vivo data clearly demonstrate the relevance of PKA activation in mediating gametogenesis by triggering proliferative signals, some in vitro data suggest that pro-apoptotic pathways may be awakened as a "dark side" of cAMP/PKA-dependent steroidogenesis, in certain conditions. P38 mitogen-activated protein kinases (MAPK) are players of death signals in steroidogenic cells, involving downstream p53 and caspases. Although it could be hypothesized that pro-apoptotic signals, if relevant, may be required for regulating atresia of non-dominant ovarian follicles, they should be transient and counterbalanced by mitogenic signals upon FSHR interaction with opposing transducers, such as Gai proteins and $\beta$-arrestins. These molecules modulate the steroidogenic pathway via extracellular-regulated kinases (ERK1/2), phosphatidylinositol-4,5-bisphosphate 3-kinases (PI3K)/protein kinase B (AKT), calcium signaling and other intracellular signaling effectors, resulting in a complex and dynamic signaling network characterizing sex- and stage-specific gamete maturation. Even if the FSH-mediated signaling network is not yet entirely deciphered, its full comprehension is of high physiological and clinical relevance due to the crucial role covered by the hormone in regulating human development and reproduction.

Keywords: FSH, FSHR, signaling, PKA, arrestin

\section{INTRODUCTION}

Follicle-stimulating hormone (FSH) is a glycoprotein playing a central role in mammalian reproduction and development. In the ovary, FSH regulates folliculogenesis, oocyte selection, and the synthesis of sex steroid hormones, thus preparing the reproductive tract for fertilization, implantation, and pregnancy (1). In the male, this gonadotropin mediates testicular development and spermatogenesis (2). The hormone is secreted by the gonadotrope cells of the pituitary, upon pulsatile regulation by the hypothalamic gonadotropin-releasing hormone ( $\mathrm{GnRH})(3)$, and acts on 
the surface of target cells located in the gonads of both males and females, where hormone-induced cell proliferationand apoptosis-linked signals are triggered. FSH displays an $\alpha$ subunit, common to other gonadotropins and to thyrotropin, and a $\beta$ subunit specifically binding to its $G$ protein-coupled receptor (GPCR), namely FSHR (4). In silico and crystallographic structural analyzes found also interaction between the $\alpha$ subunit and FSHR, demonstrating that receptor binding is not exclusive of the $\beta$ subunit (5). Hormone binding implies conformational changes of the receptor (6) that transduce the signal via direct protein interactions at the plasma membrane, resulting in a cascade of biochemical reactions that constitute an intertwined complex signaling network (7). In this review, signaling pathways activated in gonadal cells upon FSH binding to its membrane receptor are discussed in detail, providing a comprehensive view on the downstream life and death signals regulating reproductive functions.

\section{FSHR INTERACTION WITH MEMBRANE RECEPTORS}

The FSHR has been shown to functionally and/or physically interact with other membrane receptors $(8,9)$, hence intensifying the diversity of FSH action (10). For example, the FSHR may exist as a unit of di/trimeric homomers (5). Interestingly, heterodimerization of the FSHR with the luteinizing hormone (LH) receptor (LHCGR) (11) may play a key role in regulating the ovarian growth and selection (12), by virtue of the physical interaction between these two receptors. Interestingly, intracellular signals delivered by LH at the LHCGR may be modulated by the presence of FSHR on the cell surface, and vice versa, through the formation of receptor heteromers. For example, unliganded co-expressed FSHR amplifies Gaqmediated signaling initiated at the LHCGR (13), whereas the LHCGR may inhibit FSHR-dependent cAMP production (11). In addition, other classes of receptors, such as tyrosine kinase receptors, may also contribute to the modulation of FSHR activity. The insulin-like growth factor-1 receptor (IGF-1R) is one of those, as it appears necessary for FSH-induced granulosa cell differentiation via a signaling cascade involving the thymoma viral oncogene homolog 3 (AKT3) (14). Similarly, action of the epidermal growth factor receptor (EGFR) during granulosa cell differentiation is required for activation of ERK1/2 (15). Interestingly, the interaction between FSHR and EGFR signaling networks was analyzed using an automated, logicbased approach, suggesting that the ERK1/2-pathway may be activated by EGFR-dependent signals via p38 mitogenactivated protein kinases (MAPK) (16). Moreover, this study confirmed that EGFR is trans-activated through FSHR-mediated pathways involving the proto-oncogene tyrosine-protein kinase $S R C$. On the other hand, EGFR signaling network overlaps, at least in part, that of FSHR, contributing to modulation of the ERK1/2, the phosphatidylinositol-4,5-bisphosphate 3kinases $(\mathrm{PI} 3 \mathrm{~K}) /$ protein kinase $\mathrm{B}$ (AKT), and the Janus kinase $(\mathrm{JAK}) /$ signal transducer and activator of transcription protein (STAT) pathways (16).

\section{INTRACELLULAR FSHR SIGNAL TRANSDUCING PARTNERS}

Typically, G proteins are directly activated by the FSHR, by splitting of the $\beta \gamma$ dimer from the $\alpha$ subunit (17), that act as regulators of intracellular enzymes, such as $G$ protein-coupled receptor kinases (GRKs), or adenylyl cyclase, respectively, among many others (18). Moreover, $\beta \gamma$ dimer was demonstrated to be able of modulating intracellular signaling cascades $(19,20)$.

$\mathrm{G}$ protein activation is followed by FSHR phosphorylation at the intracellular level, operated by GRKs and resulting in receptor association with $\beta$-arrestins $(21,22) . \beta$-arrestins are scaffold proteins (23) that mediate GPCR desensitization, recycling, and G protein-independent signaling (24). Another direct FSHR-interacting partner is adaptor protein, phosphotyrosine interacting with $\mathrm{PH}$ domain and leucine zipper 1 (APPL1), that is linked to the activation of the PI3K/AKT anti-apoptotic pathway and calcium ion mobilization (25). By these means, APPL1 might regulate the selection of the dominant follicle by mediating the anti-apoptotic effects exerted by FSH via inhibitory phosphorylation of forkhead homolog in rhabdomyosarcoma (FOXO1a) (26). Interestingly, APPL1 is involved in cAMP signaling exerted by GPCR activity in very early endosomal compartments, hence contributing to the spatial encoding of intracellular signaling, as shown for the LHR (27). Similarly, GAIP-interacting protein C terminus (GIPC), a PDZ protein, redirects the FSHR to pre-early endosomes, hence promoting sustained, intracellular MAPK (28). Another protein directly interacting with FSHR is the 14-3-3 $\tau$ adapter protein (29), which may contact the canonical $G$ protein-receptor interaction site located at the intracellular level and mediates the activation of the AKT-pathway (30).

In the gonads, FSH-mediated signaling results in the transcription of target genes, which include LHCGR and other genes encoding membrane receptors, protein kinases, growth factors, enzymes regulating steroid synthesis, genes involved in the regulation of cell cycle, proliferation and differentiation, apoptosis, and circadian rhythm (31-33). Despite the wide diversity of FSH target genes, effects of gonadal stimulation by the hormone was defined as both proliferative and antiapoptotic due to the positive impact on gametogenesis (34, 35) and on growth of certain cancer cells (36). Nevertheless, pro-apoptotic functions emerged as a condition related to FSH-mediated steroid production $(37,38)$. In this review, molecular mechanisms of FSH action and their relationships with downstream steroidogenic, life, and death signals regulating reproduction (Figure 1) are discussed.

\section{ACTIVATION OF THE CAMP/PKA STEROIDOGENIC PATHWAY}

While FSH is mainly known to support the maturation of gametes via Sertoli cell nurturing functions in the male, the hormone has steroidogenic activity in ovarian granulosa cells (4). This action is exerted via the protein kinase A (PKA) pathway, whose activation depends on ATP conversion into the second 


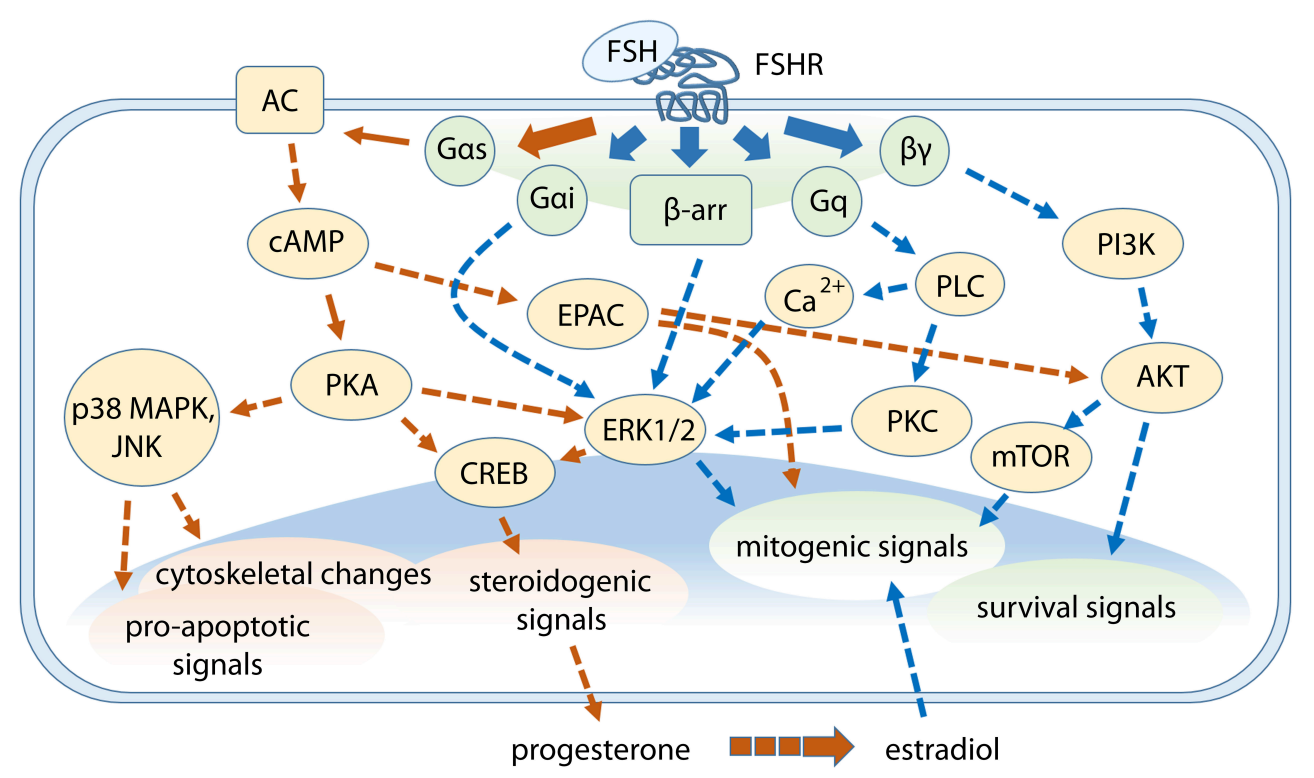

FIGURE 1 | Cross-talk between FSH-dependent steroidogenic, life, and death signals in granulosa cells. G protein subunits and $\beta$-arrestins mediate the activation of multiple signaling pathways modulating different events downstream. G $\alpha$ s protein/cAMP-related signaling are represented by orange arrows while signaling cascades depending on other FSHR intracellular interactors are indicated by blue arrows. Steroidogenic events are mainly mediated through cAMP/PKA-pathway, which is linked to p38 MAPK signaling, while ERK1/2 and AKT are key players for mitogenic and survival signals activation. Some pathways were omitted.

messenger cAMP by adenylyl cyclases, primary targets of the Gas protein subunit. The interaction between cAMP and PKA was described several decades ago (39). Intracellular cAMP increase is under the negative control of phosphodiesterase (PDE) enzymes, which metabolize the second messenger into $5^{\prime}$ AMP (40). As mentioned above, cAMP signaling is spatially and temporally compartmentalized within the cell (41). Versatility in cAMPdependent signaling depends on the expression of factors such as the isoform of adenylyl cyclase (42), PDE (43), $\beta$-arrestins (44), and A kinase anchoring proteins (AKAP) (45) that target the subcellular distribution of PKA.

In Sertoli cells, cAMP binding to PKA results in the release of PKA catalytic subunits (46) and indirectly mediates the phosphorylation of the extracellular signal-regulated kinase $1 / 2$ (ERK1/2) MAPK, in order to promote cell proliferation (47). In granulosa cells, the mechanism whereby ERK is activated likely consists in the removal of a tonic inhibition exerted by a phosphotyrosine phosphatase on MEK1 (48), recently identified as DUSP6 (49). An alternative mechanism consists in the activation of ERK1/2 by $\beta$-arrestins, with a different kinetics than $G$ proteins (Figure 2), since it is delayed and sustained (50). It was demonstrated that pERK $1 / 2$ is involved in both cAMP-dependent (51) and -independent (52) steroidogenesis. In the first case, depletion of ERK1/2 phosphorylation by specific MEK inhibition resulted in attenuated early (10$15 \mathrm{~min})$ phosphorylation of the cAMP response elementbinding protein (CREB) (51), a nuclear transcription factor up-regulating steroidogenic enzymes in gonadal cells (53). In this case, pERK $1 / 2$ inhibition negatively impacts on progesterone synthesis, indicating that cAMP-dependent ERK1/2 phosphorylation plays a stimulatory role in the rapidly delivered FSH-dependent steroidogenic signal. Interestingly, molecular mechanisms regulating steroidogenic stimuli in the Leydig cell may be different to those occurring in FSH-responsive cells. In Leydig cells, steroid hormones may be produced via ERK1/2- and CREB-dependent signaling in the absence of cAMP recruitment, via an EGFR-regulated mechanism (52). In granulosa cells, selective blockade of MAPK activation results in the inhibition of FSH-dependent StAR and progesterone synthesis while androgens to estrogen conversion by the enzyme aromatase is enhanced (54), demonstrating a differential regulation of FSHinduced sex steroid synthesis in target cells. Similar results were found by treating theca cells with $\mathrm{LH}$, that induced differential, ERK1/2-dependent regulation of progesterone and androgen production (55). However, the role of ERK $1 / 2$ in mediating steroidogenesis is a still debated matter, since it was reported to be inhibitory (56) while other studies demonstrated the positive impact of the MAPK activation on the synthesis of sex steroids (57).

\section{ROLES OF CAMP-DEPENDENT PKA ACTIVATION}

Whereas, ERK is an indirect cytosolic target of PKA that can affect CREB phosphorylation (51), the latter may be directly activated upon translocation of PKA catalytic subunit in the nucleus (48), hence inducing the transcription of CREB target genes characterized by cAMP-response elements (CRE) within their promoter region (53). Nuclear PKA was also shown 


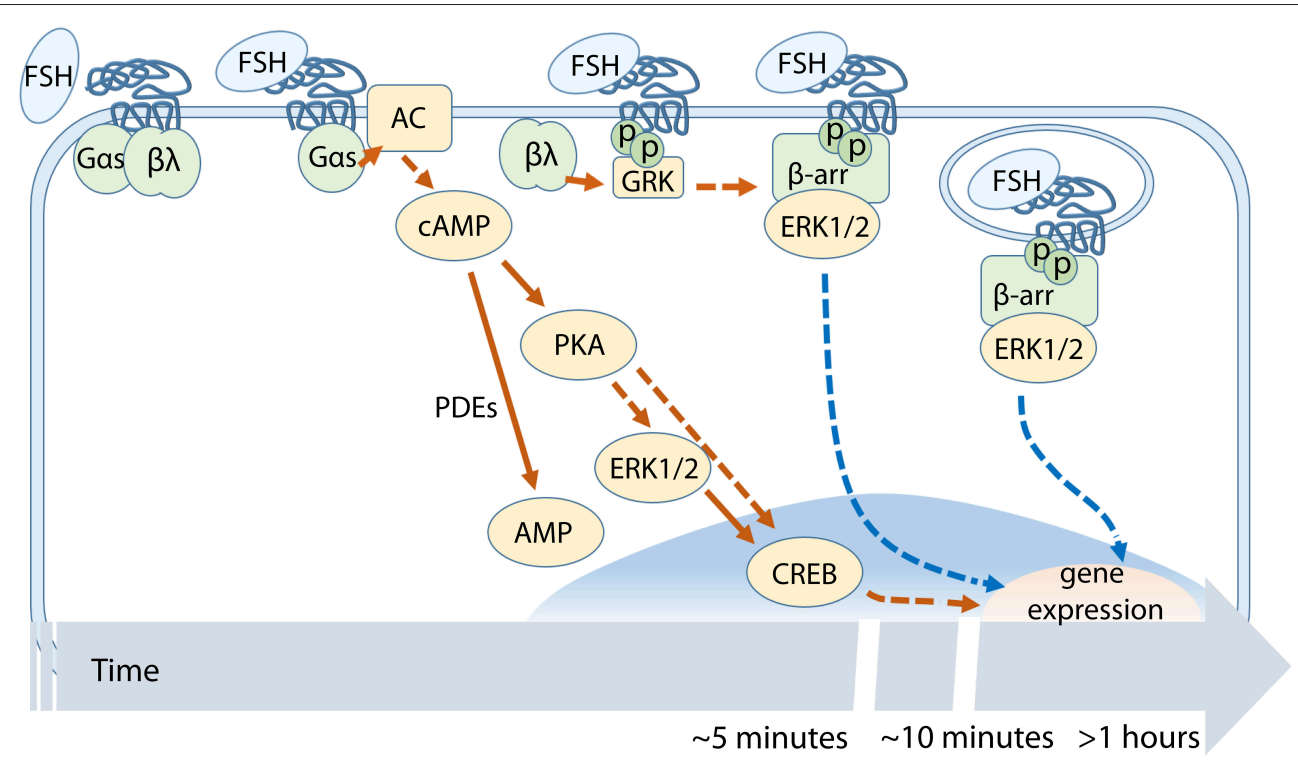

FIGURE 2 | Temporal succession of FSH-dependent events across the CAMP/PKA-pathway. cAMP-related signaling involves PKA, ERK1/2, and CREB activation. FSHR phosphorylation by GRKs occurs before $\beta$-arrestin recruitment and subsequent receptor internalization.

to phosphorylate histone $\mathrm{H} 3$, thus mediating FSH mitogenic activity in granulosa cells $(58,59)$. These interesting observations suggest that PKA could be endowed with a more general role in gene transcription, by promoting chromatin remodeling through histone $\mathrm{H} 3$ post-translational modifications. In addition, recent genome-wide experiments have highlighted that FSH-responsive genes contain far less CRE than expected in their promoters, that are notably enriched in GATA-binding sites (32).

The wide range of PKA-dependent signaling pathways suggests that the kinase is a master regulator of several FSH-dependent cell functions, especially those related to steroidogenesis and cell differentiation. However, intracellular signaling cascades regulated by PKA do not completely overlap those depending on FSH. For example, FSH induces p38 MAPK activation while PKA per se does not (60).

FSH-induced cAMP production does not only lead to activation of PKA but also of the exchange protein directly activated by cAMP (EPAC) activation. EPAC is a relatively newly discovered cAMP target mediating the activation of the small GTPases RAS and RAP and resulting in the regulation of several cell functions, such as mitogen-activated protein kinase activation, cytoskeletal changes, and calcium homeostasis (61). EPAC was suggested to be a modulator of EGFR expression (62) and granulosa cell differentiation (15) in the ovary, as well as AKT phosphorylation in Sertoli cells (63). However, the role of EPAC in the FSH-mediated signaling cascade is not yet completely elucidated.

\section{REGULATION OF PROLIFERATIVE AND PRO-APOPTOTIC SIGNALS}

In gonadal cells, part of the steroidogenic process and the proteasome are compartmentalized into different organelles, avoiding cell collapse before adequate amount of sex steroid hormones are produced (64). This function is likely enabled to limit the number of follicles that can achieve ovulation and to maintain intact the synthesis of sex steroids during the initial steps of apoptosis. These issues reflect the connection between intracellular signaling cascades regulating steroidogenic signals and pro-apoptotic stimuli, whose dominance is stage-specific, depends on several paracrine factors and is regulated via a complex intracellular network involving cAMP and activating the pro-apoptotic protein $\mathrm{p} 53$ (65). In this context, the link between cAMP/PKA and p38 MAPK activation may provide a molecular mechanism of apoptosis in steroidogenic cells. The role of p38, as well as Jun N-terminal kinase (JNK), is associated to apoptotic events in pre-ovulatory granulosa cells of primates (66), suggesting that these enzymes could be involved in the selection of the dominant follicle. This role would be counteracted by pERK1/2 activation in the dominant follicle (57), confirming the anti-apoptotic and proliferative functions mediated by this MAP kinase. Indeed, ovarian granulosa cell death is associated with reduced ERK1/2 activity, that is linked to phosphorylation of BCL-2 associated agonist of cell death (BAD) protein leading to a loss of its pro-apoptotic activity $(67,68)$.

\section{PRO- AND ANTI-APOPTOTIC PATHWAYS ARE ACTIVATED SIMULTANEOUSLY}

In steroidogenic cells, apoptosis is preceded by cell rounding, a cAMP-dependent conformational changes involving actin filaments breakdown $(69,70)$ that can be prevented by selective blockade of PKA, and also depends on p38 MAPK (71). Both PKA and p38 MAPK may be activated by FSH in a dosedependent manner, resulting in cytoskeletal rearrangements and shape changes. These data suggest that the gonadotropin 
retains both pro- and anti-apoptotic potential, exerted via p38 MAPK and ERK1/2, respectively, and this dual action of FSH provides an interesting point of view on gonadotropin functioning. On the one side, the hormone induces the synthesis of steroid hormones via the cAMP/PKA-pathway, as a requisite for gamete growth and reproduction (72). However, the steroidogenic signaling cascade is cross-linked to pro-apoptotic signals occurring through p38 MAPK, activated simultaneously and necessary for regulating steroid synthesis $(73,74)$. This cross-talk was described even in the mouse adrenal Y1 cell line, where p38 MAPK activation negatively impacts on CREB phosphorylation and StAR activity, inhibiting FSH-induced steroid synthesis (75). On the other side, survival signals are provided through the PKA/ERK1/2 signaling package, counterbalancing the pro-apoptotic effect and, to a certain extent, even inhibiting steroidogenesis (56). While further efforts should be performed to fully solve this question, some hints suggest that the FSH-dependent molecular mechanism underlying cell fate may depend on the potency and persistence of cAMP at the intracellular levels. Indeed, proliferative signals could be predominant at relatively low FSHR expression levels (38), due to preferential activation of ERK1/2 signaling through $\beta$-arrestins $(38,76)$. Relatively high and persistent intracellular cAMP levels due to $\beta$-arrestin depletion or FSHR over-expression result in caspase 3 cleavage and apoptosis (38) and this mechanism could contribute to regulating the selection of the dominant ovarian follicles (12). In granulosa cells, FSHR over-expression is linked to upregulation of pro-apoptotic genes and increased cell death, compared to cells expressing relatively low FSHR levels (77). Thus, it is possible that proliferative signals exerted via ERK1/2-pathway could be not sufficient to counteract the pro-apoptotic stimulus during the early/mid-antral follicular phase, when FSHR expression achieves maximal levels (78). In the ovary, this situation should be dynamic and transient, as well as the FSHR over-expression (78), follicle-specific and stage-dependent, in order to coordinate the maturation of one single follicle achieving ovulation while the others become atretic. This regulatory mechanism may be juxtaposed to what was previously described in Sertoli cell, that is assumed to be the male counterpart of granulosa cell. In 5-day rat Sertoli cells, the ERK1/2-pathway is stimulated by FSH upon dual coupling of FSHR to both stimulatory Gas and inhibitory Gai proteins, resulting in cyclin D1 activation and cell proliferation (47). As cells proceed throughout the differentiation program, FSH treatment is linked to consistent ERK1/2 inhibition and decreased cell proliferation, while gradually stabilizing PTEN (79). Thus, the ERK1/2 signaling pathway is a key regulator of FSH-induced life and death signals.

\section{PKC AND CALCIUM ION SIGNALING}

Increasing evidence indicates that one of the actions exerted by FSH consists in the activation of the protein kinase $\mathrm{C}$ (PKC) pathway that is involved in expansion of the cumulus, meiotic maturation of oocytes, and modulation of progesterone production in the ovary (80). Cross-talk between cAMP/PKA and PKC pathways was also described in Sertoli cells (81), where the FSH-dependent activation of these kinases is connected to calcium ion $\left(\mathrm{Ca}^{2+}\right)$ signaling (82), resulting from intracellular release as well as from rapid influx from T-type $\mathrm{Ca}^{2+}$ channels $(83,84)$ or through a Gah transglutaminase/PLC $\delta$ interaction (85). In vitro experiments in transiently FSHR over-expressing human embryonic kidney (HEK) and virally transduced human granulosa $(\mathrm{KGN})$ cells demonstrated that intracellular $\mathrm{Ca}^{2+}$ increase may occur via a molecular mechanism dependent on the interaction between APPL-1 and FSHR, and involving inositol 1,4,5-trisphosphate $\left(\mathrm{IP}_{3}\right)$ (25). Interestingly, $\mathrm{IP}_{3}$ production dampens the expression of the aromatase enzyme, at least under FSHR over-expression (86), suggesting an inhibitory role of the APPL-1/IP $3 / \mathrm{Ca}^{2+}$ signaling module on sex steroid synthesis. While further studies are required to confirm these results in the presence of physiological FSHR expression levels, these data show that APPL-1-mediated $\mathrm{Ca}^{2+}$ signaling does not necessarily depend on CAMP, as previously demonstrated (87). Moreover, human PKC belongs to a superfamily of about 15 isoenzymes activated upon Gq protein-mediated production of diacylglycerol (DAG) and/or $\mathrm{Ca}^{2+}$ by phospholipases at the intracellular level (88). In the mouse ovary, expression of PKC isoforms is dynamic and changes according to the developmental stage, from pre-puberty to the adulthood, suggesting that different isoenzymes may control specific ovarian functions, such as follicular maturation, ovulation, and luteinization (89).

It is known that PKC counteracts the PKA-mediated steroidogenesis through cAMP inhibition in granulosa $(90,91)$, and this function was further confirmed in both mammalian (92) and avian models (93). Moreover, PKC attenuates the $\mathrm{G}_{\alpha} \mathrm{s}$ protein-dependent signaling $(94,95)$, as well as proteoglycan synthesis in Sertoli cells (96). Interestingly, several reports demonstrated an up-regulatory role of PKC in Leydig cell steroidogenesis (97). Indeed, the enzyme is involved in the positive modulation of cAMP, pCREB and StAR activation, increasing the rate of steroid synthesis in the mouse Leydig MA10 cell line $(98,99)$, and in mouse primary Leydig cells $(100)$. In this case, PKC activation would not depend on FSH, due to the lack of FSHR expression in Leydig cells. On the contrary, PKC up-regulation in ovarian theca cells may be LH-dependent and negatively impacts on androstenedione synthesis in vitro (101), suggesting the existence of a sex-specific function of the kinase in regulating the synthesis of sex steroids in androgenic cells.

\section{THE PAKT ANTI-APOPTOTIC PATHWAY}

FSH binding to its receptor mediates the activation of PI3K, that are enzymes involved in the regulation of cell survival, growth and differentiation (102). In Sertoli cells, FSH increases phosphatase and tensin homolog deleted in chromosome 10 (PTEN) synthesis within minutes, independently of mRNA transcription (79), but rather mediated by FSH-mediated destabilization of several anti-PTEN miRNAs (103). PTEN stabilization in mature rat counteracts PI3K activity, when cell proliferation ceases prior puberty. AKT activation via PI3K may occur through both PKA-dependent (104) and 
independent mechanisms (63), reflecting the relevance of this kinase in modulating proliferative and anti-apoptotic signals in steroidogenic cells. Indeed, in granulosa cells, an interplay between AKT- and cAMP/PKA-pathway upregulating steroidogenesis was demonstrated (105). Moreover, FSH-dependent activation of the AKT/mammalian target of rapamycin (mTOR) signaling module (106), a positive regulator of cell cycle progression and cell proliferation (107), was also described (108-110). AKT phosphorylation was observed in mouse granulosa cells, where the kinase induces the inactivation of FOXO1 and expression of cyclin D2, resulting in cell proliferation and differentiation in response to FSH (111). In fact, recent genome-wide studies have revealed that most FSHresponsive genes in granulosa cells are FOXO target genes (33). New insights onto FSH-mediated protection from atresia came from the discovery that FOXO nuclear exclusion (inhibition) upon activation of the PIK3/AKT/mTOR signaling pathway prevents granulosa cell autophagy $(112,113)$. The relevance of pAKT activation for reproduction was highlighted by in vitro experiments where mouse preantral follicular granulosa cells were co-cultured with oocytes (114). The presence of granulosa cells inhibited oocyte apoptosis via PI3K/AKT, promoting gamete growth. Especially, AKT was described to regulate meiotic resumption in several animal models (115-117). Finally, the AKT pathway is a preferential target of $\mathrm{LH}$ (118) and its activation is even enhanced in the presence of FSH $(119,120)$, suggesting that anti-apoptotic and proliferative stimuli would be required during the late antral follicular phase to prepare the late stages of oocyte maturation and achieve ovulation. Taken together, the PI3K/AKT-pathway may act in concert with mTOR (108) regulating survival signal in the ovary. These signals are fundamental for primordial to Graafian follicles survival, as well as for oocyte maturation and growth. In this context, it is reasonable that the $\mathrm{PI} 3 \mathrm{~K} / \mathrm{AKT}$ anti-apoptotic activity mediated through FSHR is fundamental to counteract cAMP/PKA proapototic stimuli and rescue the follicle from atresia (121). In fact, dysregulation of this signaling cascade may impair female gametogenesis and it was described as a cause of infertility (122). Interesting data explaining how signals delivered through the cAMP/PKA- and PI3K/AKT-pathway are counterbalanced come from the analysis of FSH treatment of Sertoli cells. In this model, FSH has a dual, stage-dependent action. While the hormone stimulates the proliferation of immature cells through activation of PI3K/AKT-, mTOR- and ERK1/2-pathways, it preferentially stimulates cAMP production in mature Sertoli cells, resulting in PI3K/AKT inhibition and arrest of cell proliferation $(110,123)$.

\section{REFERENCES}

1. Messinis IE, Messini CI, Dafopoulos K. Novel aspects of the endocrinology of the menstrual cycle. Reproduct BioMed. (2014) 28:714-22. doi: 10.1016/j.rbmo.2014.02.003

2. Huhtaniemi I. A short evolutionary history of FSHstimulated spermatogenesis. Hormones. (2015) 14:46878. doi: $10.14310 /$ horm.2002.1632
While this effect is maybe due to the change of Sertoli cell competence, where PI3K/AKT-pathway activation becomes dependent on paracrine factors during the late stages of the maturation (124), it provides an example of dual regulation of life and death signals exerted by FSH.

\section{CONCLUSIONS}

FSH mediates multiple signaling pathways by binding to its unique GPCR (125). At the intracellular level, FSH is capable of promoting cell growth and survival opposed to steroidogenic signals cross-linked to apoptosis, resulting in a fine-tuned regulation of the gametogenesis and, in general, of reproduction. In the male gonads, FSH induces proliferation of Sertoli cells via AKT- and ERK1/2-pathways and the role of these signaling cascades, which are proliferative and anti-apoptotic, is reflected during folliculogenesis, oocyte maturation, and growth in the ovary. The synthesis of steroid hormones mainly mediated by cAMP/PKA-pathway activation is a primary endpoint in FSH functioning in the granulosa cell during the antral stage of folliculogenesis. Estrogens are the final products required for proper development of the dominant follicle, at the cost of scarifying others which become atretic. It is well known that follicular atresia is due to lowering of FSH support. However, in vitro data support unexpected, stage-specific pro-apoptotic signals delivered by the hormone that may play a role in vivo and this issue merits further investigations.

\section{AUTHOR CONTRIBUTIONS}

All authors listed have made a substantial, direct and intellectual contribution to the work, and approved it for publication.

\section{ACKNOWLEDGMENTS}

Authors are grateful to the Italian Ministry of University and Research for supporting the Department of Biomedical, Metabolic, and Neural Sciences (University of Modena and Reggio Emilia, Italy) in the context of the Departments of Excellence Programme. We are also indebted to the Institut National de la Recherche Agronomique PHASE Department, to the Centre National de la Recherche Scientifique, the French National Research Agency under the program Investissements d'avenir Grant Agreement LabEx MabImprove: ANR-10-LABX53, and to the GPCRAb (ARD2020 BIOMEDICAMENTS, contract \#32000593) grants from Région Center. 
5. Jiang X, Fischer D, Chen X, McKenna SD, Liu H, Sriraman V, et al. Evidence for follicle-stimulating hormone receptor as a functional trimer. J Biol Chem. (2014) 289:14273-82. doi: 10.1074/jbc.M114.549592

6. Jiang X, Liu H, Chen X, Chen P-H, Fischer D, Sriraman V, et al. Structure of follicle-stimulating hormone in complex with the entire ectodomain of its receptor. Proc Natl Acad Sci. (2012) 109:124916. doi: 10.1073/pnas.1206643109

7. Gloaguen P, Crépieux P, Heitzler D, Poupon A, Reiter E. Mapping the folliclestimulating hormone-induced signaling networks. Front Endocrinol. (2011) 2:45. doi: 10.3389/fendo.2011.00045

8. Jonas KC, Rivero-Müller A, Huhtaniemi IT, Hanyaloglu AC. G proteincoupled receptor transactivation. Methods Cell Biol. (2013) 117:43350. doi: 10.1016/B978-0-12-408143-7.00023-2

9. Rivero-Muller A, Chou Y-Y, Ji I, Lajic S, Hanyaloglu AC, Jonas K, et al. Rescue of defective $G$ protein-coupled receptor function in vivo by intermolecular cooperation. Proc Natl Acad Sci. (2010) 107:231924. doi: 10.1073/pnas.0906695106

10. Ulloa-Aguirre A, Reiter E, Crépieux P. FSH receptor signaling: complexity of interactions and signal diversity. Endocrinology. (2018) 159:302035. doi: 10.1210/en.2018-00452

11. Feng $X$, Zhang M, Guan R, Segaloff DL. Heterodimerization between the lutropin and follitropin receptors is associated with an attenuation of hormone-dependent signaling. Endocrinology. (2013) 154:3925-30. doi: 10.1210/en.2013-1407

12. Casarini L, Santi D, Simoni M, Potì F. 'Spare' luteinizing hormone receptors: facts and fiction. Trends Endocrinol Metabol. (2018) 29:20817. doi: 10.1016/j.tem.2018.01.007

13. Jonas KC, Chen S, Virta M, Mora J, Franks S, Huhtaniemi I, et al. Temporal reprogramming of calcium signalling via crosstalk of gonadotrophin receptors that associate as functionally asymmetric heteromers. Sci Rep. (2018) 8:2239. doi: 10.1038/s41598-018-20722-5

14. Baumgarten SC, Convissar SM, Fierro MA, Winston NJ, Scoccia B, Stocco C. IGF1R signaling is necessary for FSH-induced activation of AKT and differentiation of human cumulus granulosa cells. J Clin Endocrinol Metabol. (2014) 99:2995-3004. doi: 10.1210/jc.2014-1139

15. Wayne CM, Fan H-Y, Cheng X, Richards JS. Follicle-stimulating hormone induces multiple signaling cascades: evidence that activation of Rous sarcoma oncogene, RAS, and the epidermal growth factor receptor are critical for granulosa cell differentiation. Mol Endocrinol. (2007) 21:194057. doi: 10.1210/me.2007-0020

16. Rougny A, Gloaguen P, Langonné N, Reiter E, Crépieux P, Poupon A, et al. A logic-based method to build signaling networks and propose experimental plans. Sci Rep. (2018) 8:7830. doi: 10.1038/s41598-018-26006-2

17. Kahn RA, Gilman AG. ADP-ribosylation of Gs promotes the dissociation of its alpha and beta subunits. J Biol Chem. (1984) 259:6235-40.

18. De Pascali F, Tréfier A, Landomiel F, Bozon V, Bruneau G, Yvinec R, et al. "Follicle-stimulating hormone receptor: advances and remaining challenges." Int Rev Cell Mol Biol. (2018) 338:1-58. doi: 10.1016/bs.ircmb.2018.02.001

19. Federman AD, Conklin BR, Schrader KA, Reed RR, Bourne HR. Hormonal stimulation of adenylyl cyclase through Gi-protein beta gamma subunits. Nature. (1992) 356:159-61. doi: 10.1038/356159a0

20. Koch WJ, Hawes BE, Inglese J, Luttrell LM, Lefkowitz RJ. Cellular expression of the carboxyl terminus of a $\mathrm{G}$ protein-coupled receptor kinase attenuates G beta gamma-mediated signaling. J Biol Chem. (1994) 269:6193-7.

21. Troispoux C, Guillou F, Elalouf JM, Firsov D, Iacovelli L, De Blasi A, et al. Involvement of $\mathrm{G}$ protein-coupled receptor kinases and arrestins in desensitization to follicle-stimulating hormone action. Mol Endocrinol. (1999) 13:1599-614. doi: 10.1210/mend.13.9.0342

22. Krishnamurthy $\mathrm{H}$, Galet $\mathrm{C}$, Ascoli M. The association of arrestin-3 with the follitropin receptor depends on receptor activation and phosphorylation. Mol Cell Endocrinol. (2003) 204:127-40. doi: 10.1016/S0303-7207(03)00088-1

23. Crépieux P, Poupon A, Langonné-Gallay N, Reiter E, Delgado J, Schaefer $\mathrm{MH}$, et al. A comprehensive view of the $\beta$-arrestinome. Front Endocrinol. (2017) 8:32. doi: 10.3389/fendo.2017.00032
24. De Pascali F, Reiter E. $\beta$-arrestins and biased signalling in gonadotropin receptors. Miner Ginecol. (2018) 70:52538. doi: 10.23736/S0026-4784.18.04272-7

25. Thomas RM, Nechamen CA, Mazurkiewicz JE, Ulloa-Aguirre A, Dias JA. The adapter protein APPL1 links FSH receptor to inositol 1,4,5-trisphosphate production and is implicated in intracellular $\mathrm{Ca} 2+$ mobilization. Endocrinology. (2011) 152:1691-701. doi: 10.1210/en.2010-1353

26. Nechamen CA, Thomas RM, Cohen BD, Acevedo G, Poulikakos PI, Testa $\mathrm{JR}$, et al. Human follicle-stimulating hormone (FSH) receptor interacts with the adaptor protein APPL1 in HEK 293 cells: potential involvement of the PI3K pathway in FSH signaling. Biol Reproduc. (2004) 71:62936. doi: 10.1095/biolreprod.103.025833

27. Sposini S, Jean-Alphonse FG, Ayoub MA, Oqua A, West C, Lavery $\mathrm{S}$, et al. Integration of GPCR signaling and sorting from very early endosomes via opposing APPL1 mechanisms. Cell Rep. (2017) 21:285567. doi: 10.1016/j.celrep.2017.11.023

28. Jean-Alphonse F, Bowersox S, Chen S, Beard G, Puthenveedu MA, Hanyaloglu AC. Spatially restricted G protein-coupled receptor activity via divergent endocytic compartments. J Biol Chem. (2014) 289:396077. doi: 10.1074/jbc.M113.526350

29. Cohen BD, Nechamen CA, Dias JA. Human follitropin receptor (FSHR)

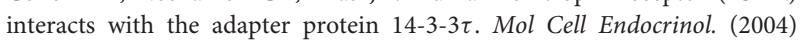
220:1-7. doi: 10.1016/j.mce.2004.04.012

30. Dias JA, Mahale SD, Nechamen CA, Davydenko O, Thomas RM, Ulloa-Aguirre A. Emerging roles for the FSH receptor adapter protein APPL1 and overlap of a putative 14-3-3 $\tau$ interaction domain with a canonical G-protein interaction site. Mol Cell Endocrinol. (2010) 329:1725. doi: 10.1016/j.mce.2010.05.009

31. Friedmann S, Sarit F, Dantes A, Ada D, Amsterdam A, Abraham A. Ovarian transcriptomes as a tool for a global approach of genes modulated by gonadotropic hormones in human ovarian granulosa cells. Endocrine. (2005) 26:259-65. doi: 10.1385/ENDO:26:3:259

32. Perlman S, Bouquin T, van den Hazel B, Jensen TH, Schambye HT, Knudsen $\mathrm{S}$, et al. Transcriptome analysis of FSH and FSH variant stimulation in granulosa cells from IVM patients reveals novel regulated genes. MHR Basic Sci Reproduc Med. (2006) 12:135-44. doi: 10.1093/molehr/gah247

33. Herndon MK, Law NC, Donaubauer EM, Kyriss B, Hunzicker-Dunn M. Forkhead box O member FOXO1 regulates the majority of folliclestimulating hormone responsive genes in ovarian granulosa cells. Mol Cell Endocrinol. (2016) 434:116-26. doi: 10.1016/j.mce.2016.06.020

34. Plant TM, Marshall GR. The functional significance of FSH in spermatogenesis and the control of its secretion in male primates. Endocr Rev. (2001) 22:764-86. doi: 10.1210/edrv.22.6.0446

35. Hillier SG. Gonadotropic control of ovarian follicular growth and development. Mol Cell Endocrinol. (2001) 179:3946. doi: 10.1016/S0303-7207(01)00469-5

36. Choi J-H, Wong AST, Huang H-F, Leung PCK. Gonadotropins and ovarian cancer. Endocr Rev. (2007) 28:440-61. doi: 10.1210/er.2006-0036

37. Amsterdam A, Sasson R, Keren-Tal I, Aharoni D, Dantes A, Rimon E, et al. Alternative pathways of ovarian apoptosis: death for life. Biochem Pharmacol. (2003) 66:1355-62. doi: 10.1016/S0006-2952(03)00485-4

38. Casarini L, Reiter E, Simoni M. $\beta$-arrestins regulate gonadotropin receptormediated cell proliferation and apoptosis by controlling different FSHR or LHCGR intracellular signaling in the hGL5 cell line. Mol Cell Endocrinol. (2016) 437:11-21. doi: 10.1016/j.mce.2016.08.005

39. Gilman AG. A protein binding assay for adenosine 3':5'-cyclic monophosphate. Proc Natl Acad Sci USA. (1970) 67:305-12.

40. Conti M, Andersen CB, Richard F, Mehats C, Chun SY, Horner K, et al. Role of cyclic nucleotide signaling in oocyte maturation. Mol Cell Endocrinol. (2002) 187:153-9. doi: 10.1016/S0303-7207(01)00686-4

41. Sposini S, Hanyaloglu AC. Evolving view of membrane trafficking and signaling systems for G protein-coupled receptors. Prog Mol Subcell Biol. (2018) 57:273-99. doi: 10.1007/978-3-319-96704-2_10

42. Johnstone TB, Agarwal SR, Harvey RD, Ostrom RS. cAMP signaling compartmentation: adenylyl cyclases as anchors of dynamic signaling complexes. Mol Pharmacol. (2018) 93:270-6. doi: 10.1124/mol.117.110825 
43. Conti M, Kasson BG, Hsueh AJ. Hormonal regulation of $3^{\prime}, 5^{\prime}$-adenosine monophosphate phosphodiesterases in cultured rat granulosa cells. Endocrinology. (1984) 114:2361-8. doi: 10.1210/endo-114-6-2361

44. Tréfier A, Musnier A, Landomiel F, Bourquard T, Boulo T, Ayoub MA, et al. $G$ protein-dependent signaling triggers a $\beta$-arrestin-scaffolded p70S6K/ rpS6 module that controls 5' TOP mRNA translation. FASEB J. (2018) 32:1154-69. doi: 10.1096/fj.201700763R

45. Carr DW, DeManno DA, Atwood A, Hunzicker-Dunn M, Scott JD. Folliclestimulating hormone regulation of A-kinase anchoring proteins in granulosa cells. J Biol Chem. (1993) 268:20729-32.

46. Landmark BF, Fauske B, Eskild W, Skalhegg B, Lohmann SM, Hansson V, et al. Identification, characterization, and hormonal regulation of $3^{\prime}, 5^{\prime}$-cyclic adenosine monophosphate dependent protein kinases in rat sertoli cells*. Endocrinology. (1991) 129:2345-54. doi: 10.1210/endo-129-5-2345

47. Crépieux P, Marion S, Martinat N, Fafeur V, Vern YL, Kerboeuf D, et al. The ERK-dependent signalling is stage-specifically modulated by FSH, during primary Sertoli cell maturation. Oncogene. (2001) 20:4696709. doi: $10.1038 /$ sj.onc. 1204632

48. Cottom J, Salvador LM, Maizels ET, Reierstad S, Park Y, Carr DW, et al. Follicle-stimulating hormone activates extracellular signal-regulated kinase but not extracellular signal-regulated kinase kinase through a 100-kDa phosphotyrosine phosphatase. J Biol Chem. (2003) 278:716779. doi: 10.1074/jbc.M203901200

49. Law NC, Donaubauer EM, Zeleznik AJ, Hunzicker-Dunn M. How protein kinase A activates canonical tyrosine kinase signaling pathways to promote granulosa cell differentiation. Endocrinology. (2017) 158:204351. doi: 10.1210/en.2017-00163

50. Kara E, Crépieux P, Gauthier C, Martinat N, Piketty V, Guillou F, et al. A phosphorylation cluster of five serine and threonine residues in the C-terminus of the follicle-stimulating hormone receptor is important for desensitization but not for beta-arrestin-mediated ERK activation. Mol Endocrinol. (2006) 20:3014-26. doi: 10.1210/me.2006-0098

51. Casarini L, Moriondo V, Marino M, Adversi F, Capodanno F, Grisolia C, et al. FSHR polymorphism p.N680S mediates different responses to FSH in vitro. Mol Cell Endocrinol. (2014) 393:83-91. doi: 10.1016/j.mce.2014.06.013

52. Manna PR, Chandrala SP, Jo Y, Stocco DM. cAMP-independent signaling regulates steroidogenesis in mouse Leydig cells in the absence of StAR phosphorylation. J Mol Endocrinol. (2006) 37:81-95. doi: 10.1677/jme.1.02065

53. Montminy MR, Bilezikjian LM. Binding of a nuclear protein to the cyclicAMP response element of the somatostatin gene. Nature. (1987) 328:1758. doi: 10.1038/328175a0

54. Moore RK, Otsuka F, Shimasaki S. Role of ERK1/2 in the differential synthesis of progesterone and estradiol by granulosa cells. Biochem Biophys Res Commun. (2001) 289:796-800. doi: 10.1006/bbrc.2001.6052

55. Tajima K, Yoshii K, Fukuda S, Orisaka M, Miyamoto K, Amsterdam $A$, et al. Luteinizing hormone-induced extracellular-signal regulated kinase activation differently modulates progesterone and androstenedione production in bovine theca cells. Endocrinology. (2005) 146:290310. doi: 10.1210/en.2005-0093

56. Amsterdam A, Hanoch T, Dantes A, Tajima K, Strauss JF, Seger R. Mechanisms of gonadotropin desensitization. Mol Cell Endocrinol. (2002) 187:69-74. doi: 10.1016/S0303-7207(01)00701-8

57. Peter AT, Dhanasekaran N. Apoptosis of granulosa cells: a review on the role of MAPK-signalling modules. Reproduc Domestic Anim. (2003) 38:20913. doi: 10.1046/j.1439-0531.2003.00438.x

58. Salvador LM, Park Y, Cottom J, Maizels ET, Jones JC, Schillace RV, et al. Follicle-stimulating hormone stimulates protein kinase A-mediated histone $\mathrm{H} 3$ phosphorylation and acetylation leading to select gene activation in ovarian granulosa cells. J Biol Chem. (2001) 276:4014655. doi: 10.1074/jbc.M106710200

59. DeManno DA, Cottom JE, Kline MP, Peters CA, Maizels ET, Hunzicker-Dunn M. Follicle-stimulating hormone promotes histone H3 phosphorylation on serine-10. Mol Endocrinol. (1999) 13:91-105. doi: 10.1210/mend.13.1.0222

60. Puri P, Little-Ihrig L, Chandran U, Law NC, Hunzicker-Dunn M, Zeleznik AJ. Protein kinase A: a master kinase of granulosa cell differentiation. Sci Rep. (2016) 6:28132. doi: 10.1038/srep28132
61. Schmidt M, Dekker FJ, Maarsingh H. Exchange protein directly activated by cAMP (epac): a multidomain cAMP mediator in the regulation of diverse biological functions. Pharmacol Rev. (2013) 65:670-709. doi: 10.1124/pr.110.003707

62. Choi J-H, Chen C-L, Poon SL, Wang H-S, Leung PCK. Gonadotropinstimulated epidermal growth factor receptor expression in human ovarian surface epithelial cells: involvement of cyclic AMP-dependent exchange protein activated by cAMP pathway. Endocr Relat Cancer. (2009) 16:17988. doi: 10.1677/ERC-07-0238

63. Meroni SB, Riera MF, Pellizzari EH, Cigorraga SB. Regulation of rat Sertoli cell function by FSH: possible role of phosphatidylinositol 3-kinase/protein kinase B pathway. J Endocrinol. (2002) 174:195-204. doi: 10.1677/joe.0.1740195

64. Amsterdam A, Dantes A, Selvaraj N, Aharoni D. Apoptosis in steroidogenic cells: structure-function analysis. Steroids. (1997) 62:207-11. doi: 10.1016/S0039-128X(96)00182-1

65. Amsterdam A, Gold RS, Hosokawa K, Yoshida Y, Sasson R, Jung $\mathrm{Y}$, et al. Crosstalk among multiple signaling pathways controlling ovarian cell death. Trends Endocrinol Metabol. (1999) 10:255-62. doi: 10.1016/S1043-2760(99)00164-2

66. Uma J, Muraly P, Verma-Kumar S, Medhamurthy R. Determination of onset of apoptosis in granulosa cells of the preovulatory follicles in the bonnet monkey (Macaca radiata): correlation with mitogen-activated protein kinase activities. Biol Reproduc. (2003) 69:1379-87. doi: 10.1095/biolreprod.103.017897

67. Shiota M, Sugai N, Tamura M, Yamaguchi R, Fukushima N, Miyano T, et al. Correlation of mitogen-activated protein kinase activities with cell survival and apoptosis in porcine granulosa cells. Zool Sci. (2003) 20:193201. doi: 10.2108/zsj.20.193

68. Gebauer G, Peter AT, Onesime D, Dhanasekaran N. Apoptosis of ovarian granulosa cells: correlation with the reduced activity of ERK-signaling module. J Cell Biochem. (1999) 75:54754. doi: 10.1002/(SICI)1097-4644(19991215)75:43.3.CO;2-X

69. Schiffer Z, Keren-Tal I, Deutsch M, Dantes A, Aharoni D, Weinerb A, et al. Fourier analysis of differential light scattering for the quantitation of FSH response associated with structural changes in immortalized granulosa cells. Mol Cell Endocrinol. (1996) 118:145-53. doi: 10.1016/0303-7207(96)03774-4

70. Amsterdam A, Dantes A, Liscovitch M. Role of phospholipase-D and phosphatidic acid in mediating gonadotropin-releasing hormone-induced inhibition of preantral granulosa cell differentiation. Endocrinology. (1994) 135:1205-11. doi: 10.1210/endo.135.3.8070364

71. Maizels ET, Cottom J, Jones JC, Hunzicker-Dunn M. Follicle stimulating hormone (FSH) activates the p38 mitogen-activated protein kinase pathway, inducing small heat shock protein phosphorylation and cell rounding in immature rat ovarian granulosa cells. Endocrinology. (1998) 139:33536. doi: 10.1210/endo.139.7.6188

72. Di Giacomo M, Camaioni A, Klinger FG, Bonfiglio R, Salustri A. Cyclic AMP-elevating Agents promote cumulus cell survival and hyaluronan matrix stability, thereby prolonging the time of mouse oocyte fertilizability. $J$ Biol Chem. (2016) 291:3821-36. doi: 10.1074/jbc.M115.680983

73. Yu F-Q, Han C-S, Yang W, Jin X, Hu Z-Y, Liu Y-X. Activation of the p38 MAPK pathway by follicle-stimulating hormone regulates steroidogenesis in granulosa cells differentially. J Endocrinol. (2005) 186:8596. doi: 10.1677/joe.1.05955

74. Inagaki K, Otsuka F, Miyoshi T, Yamashita M, Takahashi M, Goto J, et al. p38-mitogen-activated protein kinase stimulated steroidogenesis in granulosa cell-oocyte cocultures: role of bone morphogenetic proteins 2 and 4. Endocrinology. (2009) 150:1921-30. doi: 10.1210/en.2008-0851

75. Li J, Zhou Q, Ma Z, Wang M, Shen W-J, Azhar S, et al. Feedback inhibition of CREB signaling by p38 MAPK contributes to the negative regulation of steroidogenesis. Reproduc Biol Endocrinol. (2017) 15:19. doi: 10.1186/s12958-017-0239-4

76. Tranchant T, Durand G, Gauthier C, Crépieux P, Ulloa-Aguirre A, Royère $D$, et al. Preferential $\beta$-arrestin signalling at low receptor density revealed by functional characterization of the human FSH receptor A189 V mutation?. Mol Cell Endocrinol. (2011) 331:109-18. doi: 10.1016/j.mce.2010.08.016

77. Sasson R, Dantes A, Tajima K, Amsterdam A. Novel genes modulated by FSH in normal and immortalized FSH-responsive cells: new 
insights into the mechanism of FSH action. FASEB J. (2003) 17:1256-66. doi: 10.1096/fj.02-0740com

78. Jeppesen JV, Kristensen SG, Nielsen ME, Humaidan P, Dal Canto M, Fadini $\mathrm{R}$, et al. LH-receptor gene expression in human granulosa and cumulus cells from antral and preovulatory follicles. J Clin Endocrinol Metabol. (2012) 97:E1524-31. doi: 10.1210/jc.2012-1427

79. Dupont J, Musnier A, Decourtye J, Boulo T, Lécureuil C, Guillou H, et al. FSH-stimulated PTEN activity accounts for the lack of FSH mitogenic effect in prepubertal rat Sertoli cells. Mol Cell Endocrinol. (2010) 315:2716. doi: 10.1016/j.mce.2009.09.016

80. Yamashita Y, Okamoto M, Ikeda M, Okamoto A, Sakai M, Gunji Y, et al. Protein kinase C (PKC) increases TACE/ADAM17 enzyme activity in porcine ovarian somatic cells, which is essential for granulosa cell luteinization and oocyte maturation. Endocrinology. (2014) 155:108090. doi: 10.1210/en.2013-1655

81. Gorczynska E, Spaliviero J, Handelsman DJ. The relationship between 3'5'-cyclic adenosine monophosphate and calcium in mediating folliclestimulating hormone signal transduction in Sertoli cells. Endocrinology. (1994) 134:293-300. doi: 10.1210/endo.134.1.8275946

82. Meroni S, Cánepa D, Pellizzari E, Schteingart H, Cigorraga S. Regulation of gamma-glutamyl transpeptidase activity by $\mathrm{Ca}(2+)$ - and protein kinase C-dependent pathways in Sertoli cells. Int J Androl. (1997) 20:18994. doi: 10.1046/j.1365-2605.1997.00053.x

83. Flores JA, Veldhuis JD, Leong DA. Follicle-stimulating hormone evokes an increase in intracellular free calcium ion concentrations in single ovarian (granulosa) cells. Endocrinology. (1990) 127:3172-9. doi: 10.1210/endo-127-6-3172

84. Loss ES, Jacobus AP, Wassermann GF. Rapid signaling responses in Sertoli cell membranes induced by follicle stimulating hormone and testosterone: calcium inflow and electrophysiological changes. Life Sci. (2011) 89:57783. doi: 10.1016/j.lfs.2011.05.017

85. Lin Y-F, Tseng M-J, Hsu H-L, Wu Y-W, Lee Y-H, Tsai Y-H. A novel folliclestimulating hormone-induced $\mathrm{G}$ alpha $\mathrm{h} / \mathrm{phospholipase} \mathrm{C-delta1}$ signaling pathway mediating rat sertoli cell Ca2+-influx. Mol Endocrinol. (2006) 20:2514-27. doi: 10.1210/me.2005-0347

86. Donadeu FX, Ascoli M. The differential effects of the gonadotropin receptors on aromatase expression in primary cultures of immature rat granulosa cells are highly dependent on the density of receptors expressed and the activation of the inositol phosphate cascade. Endocrinology. (2005) 146:3907-16. doi: 10.1210/en.2005-0403

87. Flores JA, Leong DA, Veldhuis JD. Is the calcium signal induced by folliclestimulating hormone in swine granulosa cells mediated by adenosine cyclic 3'5'-monophosphate-dependent protein kinase? Endocrinology. (1992) 130:1862-6. doi: 10.1210/endo.130.4.1547716

88. Mellor H, Parker PJ. The extended protein kinase C superfamily. Biochem J. (1998) 332(Pt 2):281-92. doi: 10.1042/bj3320281

89. Tepekoy F, Ustunel I, Akkoyunlu G. Protein kinase C isoforms $\alpha, \delta$ and $\varepsilon$ are differentially expressed in mouse ovaries at different stages of postnatal development. J Ovarian Res. (2014) 7:117. doi: 10.1186/s13048-014-0117-z

90. Manna PR, Pakarainen P, Rannikko AS, Huhtaniemi IT. Mechanisms of desensitization of follicle-stimulating hormone (FSH) action in a murine granulosa cell line stably transfected with the human FSH receptor complementary deoxyribonucleic acid. Mol Cell Endocrinol. (1998) 146:16376. doi: 10.1016/S0303-7207(98)00156-7

91. González Reyes J, Santana P, González Robaina I, Cabrera Oliva J, Estévez F, Hernández I, et al. Effect of the protein phosphatase inhibitor okadaic acid on FSH-induced granulosa cell steroidogenesis. J Endocrinol. (1997) 152:131-9. doi: 10.1677/joe.0.1520131

92. Nemer A, Azab AN, Rimon G, Lamprecht S, Ben-Menahem D. Different roles of cAMP/PKA and PKC signaling in regulating progesterone and PGE2 levels in immortalized rat granulosa cell cultures. Gen Comp Endocrinol. (2018) 269:88-95. doi: 10.1016/j.ygcen.2018.08.019

93. Jamaluddin M, Molnár M, Marrone BL, Hertelendy F. Signal transduction in avian granulosa cells: effects of protein kinase C inhibitors. Gen Comp Endocrinol. (1994) 93:471-9. doi: 10.1006/gcen.1994.1051

94. Eskola V, Ryhänen P, Savisalo M, Rannikko A, Kananen K, Sprengel R, et al. Stable transfection of the rat follicle-stimulating hormone receptor complementary DNA into an immortalized murine Sertoli cell line. Mol Cell Endocrinol. (1998) 139:143-52. doi: 10.1016/S0303-7207(98)00063-X

95. Eikvar L, Taskén KA, Eskild W, Hansson V. Protein kinase C activation and positive and negative agonist regulation of 3,5'-cyclic adenosine monophosphate levels in cultured rat Sertoli cells. Acta Endocrinol. (1993) 128:568-72. doi: 10.1530/acta.0.1280568

96. Fagnen G, Phamantu NT, Bocquet J, Bonnamy PJ. Activation of protein kinase $\mathrm{C}$ increases proteoglycan synthesis in immature rat Sertoli cells. Biochim Biophys Acta. (1999) 1472:25061. doi: 10.1016/S0304-4165(99)00128-2

97. Cooke BA, Choi MC, Dirami G, Lopez-Ruiz MP, West AP. Control of steroidogenesis in Leydig cells. J Steroid Biochem Mol Biol. (1992) 43:4459. doi: 10.1016/0960-0760(92)90083-U

98. Manna PR, Soh J-W, Stocco DM. The involvement of specific PKC isoenzymes in phorbol ester-mediated regulation of steroidogenic acute regulatory protein expression and steroid synthesis in mouse leydig cells. Endocrinology. (2011) 152:313-25. doi: 10.1210/en.2010-0874

99. Manna PR, Huhtaniemi IT, Stocco DM. Mechanisms of protein kinase $\mathrm{C}$ signaling in the modulation of $3^{\prime}, 5^{\prime}$-cyclic adenosine monophosphatemediated steroidogenesis in mouse gonadal cells. Endocrinology. (2009) 150:3308-17. doi: 10.1210/en.2008-1668

100. Costa RR, Reis RI dos, Aguiar JF, Varanda WA. Luteinizing hormone (LH) acts through PKA and PKC to modulate T-type calcium currents and intracellular calcium transients in mice Leydig cells. Cell Calcium. (2011) 49:191-9. doi: 10.1016/j.ceca.2011.02.003

101. Zachow RJ, Terranova PF. Involvement of protein kinase $\mathrm{C}$ and protein tyrosine kinase pathways in tumor necrosis factor-alpha-induced clustering of ovarian theca-interstitial cells. Mol Cell Endocrinol. (1993) 97:3749. doi: 10.1016/0303-7207(93)90209-3

102. Leevers SJ, Vanhaesebroeck B, Waterfield MD. Signalling through phosphoinositide 3-kinases: the lipids take centre stage. Curr Opin Cell Biol. (1999) 11:219-25. doi: 10.1016/S0955-0674(99)80029-5

103. Nicholls PK, Harrison CA, Walton KL, McLachlan RI, O'Donnell L, Stanton PG. Hormonal regulation of sertoli cell micro-RNAs at spermiation. Endocrinology. (2011) 152:1670-83. doi: 10.1210/en.2010-1341

104. Hunzicker-Dunn ME, Lopez-Biladeau B, Law NC, Fiedler SE, Carr DW, Maizels ET. PKA and GAB2 play central roles in the FSH signaling pathway to PI3K and AKT in ovarian granulosa cells. Proc Natl Acad Sci. (2012) 109:E2979-88. doi: 10.1073/pnas.1205661109

105. Chen Y-J, Hsiao P-W, Lee M-T, Mason JI, Ke F-C, Hwang J-J. Interplay of PI3K and cAMP/PKA signaling, and rapamycin-hypersensitivity in TGFbetal enhancement of FSH-stimulated steroidogenesis in rat ovarian granulosa cells. J Endocrinol. (2007) 192:405-19. doi: 10.1677/JOE-06-0076

106. Rehnitz J, Alcoba DD, Brum IS, Hinderhofer K, Youness B, Strowitzki T, et al. FMR1 and AKT/mTOR signalling pathways: potential functional interactions controlling folliculogenesis in human granulosa cells. Reproduc BioMed. (2017) 35:485-93. doi: 10.1016/j.rbmo.2017.07.016

107. King D, Yeomanson D, Bryant HE. PI3King the lock: targeting the PI3K/Akt/mTOR pathway as a novel therapeutic strategy in neuroblastoma. J Pediatr Hematol/Oncol. (2015) 37:24551. doi: 10.1097/MPH.0000000000000329

108. Alam H, Maizels ET, Park Y, Ghaey S, Feiger ZJ, Chandel NS, et al. Follicle-stimulating hormone activation of hypoxia-inducible factor-1 by the phosphatidylinositol 3-kinase/AKT/Ras homolog enriched in brain (Rheb)/mammalian target of rapamycin (mTOR) pathway is necessary for induction of select protein markers of follicular differentiation. J Biol Chem. (2004) 279:19431-40. doi: 10.1074/jbc.M401235200

109. Lécureuil C, Tesseraud S, Kara E, Martinat N, Sow A, Fontaine I, et al. Follicle-stimulating hormone activates p70 ribosomal protein $\mathrm{S6}$ kinase by protein kinase A-mediated dephosphorylation of Thr 421/Ser 424 in primary Sertoli cells. Mol Endocrinol. (2005) 19:1812-20. doi: 10.1210/me.2004-0289

110. Musnier A, Heitzler D, Boulo T, Tesseraud S, Durand G, Lécureuil C, et al. Developmental regulation of p70 S6 kinase by a $\mathrm{G}$ protein-coupled receptor dynamically modelized in primary cells. Cell Mol Life Sci. (2009) 66:3487-503. doi: 10.1007/s00018-009-0134-Z

111. Park Y, Maizels ET, Feiger ZJ, Alam H, Peters CA, Woodruff TK, et al. Induction of cyclin D2 in rat granulosa cells requires FSH-dependent relief 
from FOXO1 repression coupled with positive signals from Smad. J Biol Chem. (2005) 280:9135-48. doi: 10.1074/jbc.M409486200

112. Shen M, Jiang Y, Guan Z, Cao Y, Sun S-C, Liu H. FSH protects mouse granulosa cells from oxidative damage by repressing mitophagy. Sci Rep. (2016) 6:38090. doi: 10.1038/srep38090

113. Shen M, Jiang Y, Guan Z, Cao Y, Li L, Liu H, et al. Protective mechanism of FSH against oxidative damage in mouse ovarian granulosa cells by repressing autophagy. Autophagy. (2017) 13:1364-85. doi: 10.1080/15548627.2017.1327941

114. Li Z, Zhang P, Zhang Z, Pan B, Chao H, Li L, et al. A co-culture system with preantral follicular granulosa cells in vitro induces meiotic maturation of immature oocytes. Histochem Cell Biol. (2011) 135:51322. doi: 10.1007/s00418-011-0812-4

115. Kalous J, Kubelka M, Šolc P, Šušor A, Motlík J. AKT (protein kinase B) is implicated in meiotic maturation of porcine oocytes. Reproduction. (2009) 138:645-54. doi: 10.1530/REP-08-0461

116. Han SJ, Vaccari S, Nedachi T, Andersen CB, Kovacina KS, Roth RA, et al. Protein kinase B/Akt phosphorylation of PDE3A and its role in mammalian oocyte maturation. EMBO J. (2006) 25:571625. doi: $10.1038 /$ sj.emboj. 7601431

117. Kishimoto T. A primer on meiotic resumption in starfish oocytes: the proposed signaling pathway triggered by maturation-inducing hormone. Mol Reproduc Dev. (2011) 78:704-7. doi: 10.1002/mrd.21343

118. Casarini L, Lispi M, Longobardi S, Milosa F, La Marca A, Tagliasacchi D, et al. LH and hCG action on the same receptor results in quantitatively and qualitatively different intracellular signalling. PLOS ONE. (2012) 7:e46682. doi: 10.1371/journal.pone.0046682

119. Casarini L, Santi D, Brigante G, Simoni M. Two hormones for one receptor: evolution, biochemistry, actions and pathophysiology of LH and hCG. Endocr Rev. (2018) 2018:65. doi: 10.1210/er.2018-00065

120. Casarini L, Riccetti L, De Pascali F, Nicoli A, Tagliavini S, Trenti T, et al. Follicle-stimulating hormone potentiates the steroidogenic activity of chorionic gonadotropin and the anti-apoptotic activity of luteinizing hormone in human granulosa-lutein cells in vitro. Mol Cell Endocrinol. (2016) 422:103-14. doi: 10.1016/j.mce.2015.12.008

121. Riccetti L, Sperduti S, Lazzaretti C, Casarini L, Simoni M. The cAMP/PKA pathway: steroidogenesis of the antral follicular stage. Miner Ginecol. (2018) 2018:4282. doi: 10.23736/S0026-4784.18.04282-X

122. Makker A, Goel MM, Mahdi AA. PI3K/PTEN/Akt and TSC/mTOR signaling pathways, ovarian dysfunction, and infertility: an update. J Mol Endocrinol. (2014) 53:R103-18. doi: 10.1530/JME-14-0220

123. Nascimento AR, Macheroni C, Lucas TFG, Porto CS, Lazari MFM. Crosstalk between FSH and relaxin at the end of the proliferative stage of rat Sertoli cells. Reproduction. (2016) 152:613-28. doi: 10.1530/ REP-16-0330

124. Meroni SB, Riera MF, Pellizzari EH, Galardo MN, Cigorraga SB. FSH activates phosphatidylinositol 3-kinase/protein kinase B signaling pathway in 20-day-old Sertoli cells independently of IGF-I. J Endocrinol. (2004) 180:257-65. doi: 10.1677/joe.0.1800257

125. Hunzicker-Dunn M, Maizels E. FSH signaling pathways in immature granulosa cells that regulate target gene expression: branching out from protein kinase A. Cell Signal. (2006) 18:1351-9. doi: 10.1016/j.cellsig.2006.02.011

Conflict of Interest Statement: The authors declare that the research was conducted in the absence of any commercial or financial relationships that could be construed as a potential conflict of interest.

Copyright (0) 2019 Casarini and Crépieux. This is an open-access article distributed under the terms of the Creative Commons Attribution License (CC BY). The use, distribution or reproduction in other forums is permitted, provided the original author(s) and the copyright owner(s) are credited and that the original publication in this journal is cited, in accordance with accepted academic practice. No use, distribution or reproduction is permitted which does not comply with these terms. 